\title{
Evaluation of the Effectiveness of the M-Area Extraction System
}

by

D. Jackson

E. I. du Pont de Nemours and Company Savannah River Site

Aiken, South Carolina 29808

S. S. Papadopulos \& Associates. Inc.

\section{DISTRIBUTION OF THIS DOCUMENT IS UNLIMITED}

DOE Contract No.

This paper was prepared in connection with work done under the above contract number with the U.S.

Department of Energy. By acceptance of this paper, the publisher and/or recipient acknowledges the U. S. Government's right to retain a nonexclusive, royalty-free license in and to any copyright covering this paper, along with the right to reproduce and to authorize others to reproduce all or part of the copyrighted paper. 


\section{DISCLAIMER}

This report was prepared as an account of work sponsored by an agency of the United States Government. Neither the United States Government nor any agency thereof, nor any of their employees, makes any warranty, express or implied, or assumes any legal liability or responsibility for the accuracy, completeness, or usefulness of any information, apparatus, product, or process disclosed, or represents that its use would not infringe privately owned rights. Reference herein to any specific commercial product, process, or service by trade name, trademark, manufacturer, or otherwise does not necessarily constitute or imply its endorsement, recommendation, or favoring by the United States Government or any agency thereof. The views and opinions of authors expressed herein do not necessarily state or reflect those of the United States Government or any agency thereof.

This report has been reproduced directly from the best available copy.

Available to DOE and DOE contractors from the Office of Scientific and Technical Information, P.O. Box 62, Oak Ridge, TN 37831; prices available from (615) 576-8401.

Available to the public from the National Technical Information Service, U.S. Department of Commerce; 5285 Port Royal Road, Springfield, VA 22161. 


\section{DISCLAMMER}

Portions of this document may be illegible in electronic image products. Images are produced from the best available original document. 

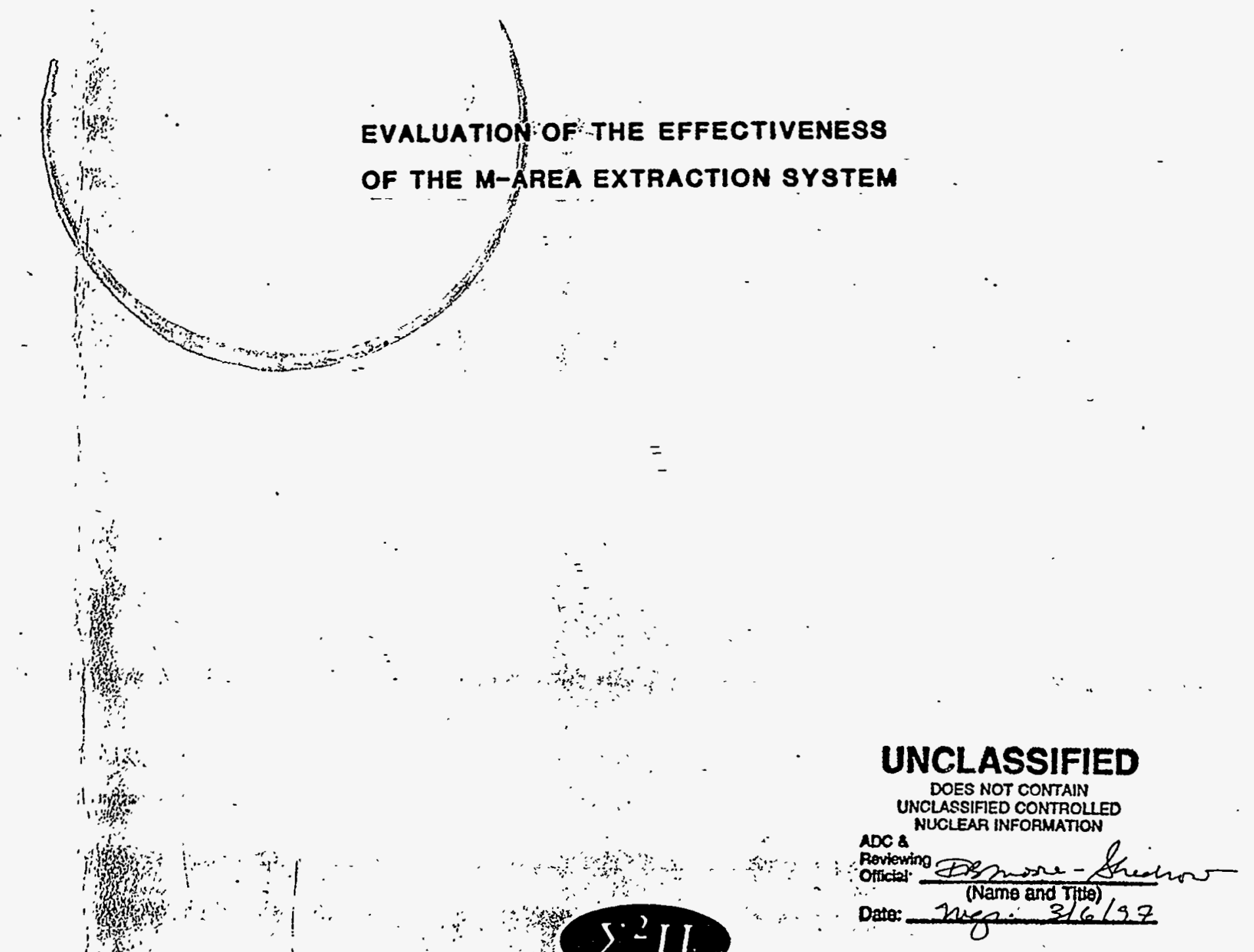


\title{
EVALUATION OF THE EFFECTIVENESS
}

\section{OF THE M-AREA EXTRACTION SYSTEM}

\author{
PREPARED FOR
}

E.I. DU PONT DE NEMOURS \& COMPANY

SAVANNAH RIVER PLANT

AIKEN. SOUTH CAROLINA

,

\section{$\Sigma^{2} \Pi$}

S. S. PAPADOPULOS \& ASSOCIATES, INC.

CONSULTING GROUND-WATER HYDROLOGISTS

12250 ROCKVILLE PIKE, SUITE 290

ROCKVILLE. MARYLAND 20852

TEL. (301) 468.5760

JULY 1980 
$\sum \Sigma^{2}$ S. S. PAPADOPUlOS \& ASSOCIATES. INC.

TABLE OF CONTENTS

Page

LIST OF FIGURES

i i

LIST OF TABLES

ii

REPORT

INTRODUCTION

1

METHODS

3

RESULTS

4

CONCLUSIONS

6

FIGURES

TABLES 
TID S. S. PAPADOPULOS \& ASSOCIATES. INC.

\section{LIST OF FIGURES}

1. General Pattern of Ground-Water Flow to an Extraction Well in the M-Area

2. Definition of Hydrogeologic Units in Ground-Water Flow Model

3. Zones of Capture of M-Area Extraction System

4. Cross-Sectional Profile of Zone of Capture of Extraction Well RWM-8

5. Average Total Volatile Organics Concentrations in 1985 and Calculated Areal Extent of Zone of Capture in Layer 3

6. Average Total Volatile Organics Concentrations in 1985 and Calculated Areal Extent of Zone of Capture in Layer 2

7. Average Total Volatile Organics Concentrations in 1985 and Calculated Areal Extent of Zone of Capture in Layer 1

\section{LIST OF TABLES}

1. Hydrogeologic Properties Used in Ground-Water Flow Model

2. Pumping Rates of M-Area Extraction Wells 


\section{EVALUATION OF THE \\ EFFECTIVENESS OF THE M-AREA EXTRACTION SYSTEM}

\section{INTRODUCTION}

The effect of the M-Area extraction system on ground-water flow patterns in the vicinity of the M-Area was investigated using the ground-water flow model. of the A- and M-Areas developed by S. S. Papadopulos \& Associates, Inc. The purpose of this investigation was to:

1) evaluate the performance of the extraction system, in terms of its capability to prevent migration of volatile organic chemicals from the M-Area, and

2) evaluate the length of time required to remove ground water from the capture zones of the extraction wells.

The effectiveness of the ground-water extraction system was evaluated by calculating where the ground water that is pumped from the extraction system enters the ground-water table as recharge, and by calculating the flow paths and travel times for this ground water from the recharge area to the extraction wells. If the ground-water flow paths to the extraction wells encompass the zones containing the chemicals of concern, the extraction system, if operated long enough, will prevent migration of the chemicals from the M-Area. The time required to reduce the concentrations of the chemicals in the ground water is a function of the pattern of ground-water velocity created by the extraction system, the properties of the chemicals of concern, the nature of the source of the chemicals, and the interaction of the chemicals with the ground-water environment. This investigation focused 
on the patterns of ground-water velocity created by the extraction system, the zones of capture for the extraction wells, and the rate of ground-water evacuation from the capture zones.

A diagram of the general ground-water flow pattern toward a typical extraction well in the M-Area is shown on Figure 1 . This diagram illustrates concepts that are important to understanding and evaluating the effectiveness of the extraction system. Figure 1 shows the ground-water flow paths toward the extraction well in both plan view and cross-section. The region that encompasses all of the flow paths that end at the well is referred to as the zone of the capture. All ground water within the zone of capture will ultimately discharge at the well (assuming that the well is operated continuousiy) and all recharge to the ground-water environment within the zone of capture will discharge at the well.

It is important to note the three-dimensional aspects of the zone of capture within the complex aquifer system in the M-Area. The recharge that occurs to the area defined by the intersection of the zone of capture with the water table equal the pumping rate of the extraction well. The pathways and the time of travel from the water table within this controlled area to the extraction wells will be influenced by the hydraulic properties of the groundwater environment as well as the rate of recharge.
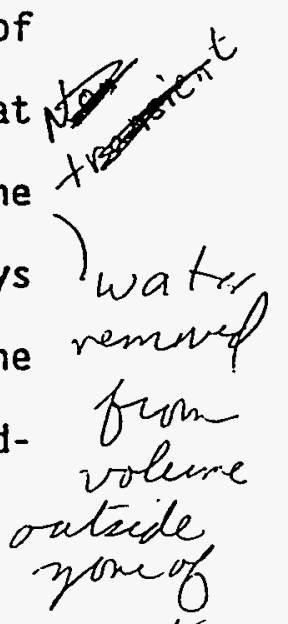

The evaluation of effectiveness of the M-Area extraction system consisted capteres. of three main work items:

1) calculation of the zones of capture for the extraction wells;

2) calculation of travel times within the zones of capture; and 
3) estimation of the extent of ground water within the M-Area that contains volatile organic chemicals.

METHODS

The zone of capture for each of the extraction wells and ground-water travel times were calculated by 1) using a ground-water flow model to determine the velocity pattern within the ground-water environment, and 2) using a particle tracking scheme to determine the flow paths and travel times from the water table to each of the extraction wells.

The ground-water flow model of the A- and M-Area will be described in a separate report, and will not be discussed in detail. The A- and M-Areas were simulated by dividing the ground-water environment into five layers as shown schematically on Figure 2. Layers 1, 2, and 3 correspond to the intervals 220-240 feet, 172-220 feet, and 135-172 feet above mean sea level, respectively. The hydraulic properties assigned to each of the layers in the ground-water flow model are listed in Table 1. The values for effective vertical hydraulic conductivity shown in Table 1 were derived from the leakage coefficients used in the ground-water flow model. In simulating the M-Area extraction system, the pumping rates listed in Table 2 were assigned to each of the extraction wells. These rates correspond to the average rate of pumping from the extraction system during November of 1985.

The particle tracking scheme used in the study is a three-dimensional analysis of ground-water flow characteristics developed by S. S. Papadopulos \& Associates, Inc. The scheme tracks particles backward from the extraction 
wells to the water table given the three-dimensional velocity distribution calculated with the ground-water flow model.

The extent of ground water containing volatile organic chemicals in the vicinity of the M-Area was calculated by adding the average concentrations of tetrachloroethene, 1,1,1-trichloroethane, and trichloroethene measured in the monitoring and extraction wells in 1985. These data were analyzed graphically to estimate the extent of ground water containing more than $100 \mathrm{ppb}$ of volatile organic chemicals within the depth intervals corresponding to layers 1,2 , and 3 in the ground-water flow model.

\section{RESULTS}

The areal extent of the zones of capture of the extraction wells at the water table (layer 1 in the model) is shown on Figure 3 . Some of the calculated flow paths are also-shown (in plan view), with tick marks delineating five-year travel-time intervals. Approximately 30 years is required for ground water to travel from the water table at the edges of the zone of capture to the extraction wells. The plan view of the zones of capture of the extraction wells within the depth interval corresponding to model layer 3 is shown as the shaded area on Figure 3 . The plan view of the capture zones within layer 3 is about 40 percent smaller than the areal extent of the capture zones at the water table. The plan view of the capture zone in layer 2 is only slightly smaller than the extent of the capture zone at the water table because ground-water movement within model layer 1 is predominantly vertical.

A cross section through the capture zone of extraction well RWM-8 is 
shown on Figure 4. The flow paths and travel times to the extraction well are also shown on this figure.

The estimated extent of ground water within the depth interval corresponding to model layer 3 that contained more than $100 \mathrm{ppb}$ of volatile organic chemicals in 1985 is shown superimposed with the calculated capture zone on Figure 5. Note that ground water containing more than $100 \mathrm{ppb}$ of volatile organics extended downgradient of the calculated zone of capture of the extraction system. Upgradient of the extraction wells, much of the region containing ground water with more than $100 \mathrm{ppb}$ of volatile organics is within the calculated zone of capture.

The calculated capture zone in layer 2 and the extent of ground water within the corresponding depth intervat containing volatile organic chemicals in excess of $100 \mathrm{ppb}$ is shown on Figure 6. A similar diagram depicting conditions in model layer 1 is shown on Figure 7. In both layers 1 and 2, the calculated capture zones encompass a large portion, but not all, of the region containing ground water with total volatile organic concentrations in excess of $100 \mathrm{ppb}$.

\section{CONCLUSIONS}

1. The ground-water extraction system in the M-Area is capturing a large part, but not a11, of the ground water containing concentrations of volatile organic chemicals that exceed $100 \mathrm{ppb}$.

2. The zones of capture for the extraction wells do not extend any appreciable distance below the depth of the wells and do not extend 
E'II S. S. PAPADOPUlOS \& ASSOCIATES. INC.

more than about 300 feet downgradient from the southernmost wells in the system.

3. The travel time from the peripheral parts of the capture zones at the water table to the extraction wells is estimated to be about 30 years. 


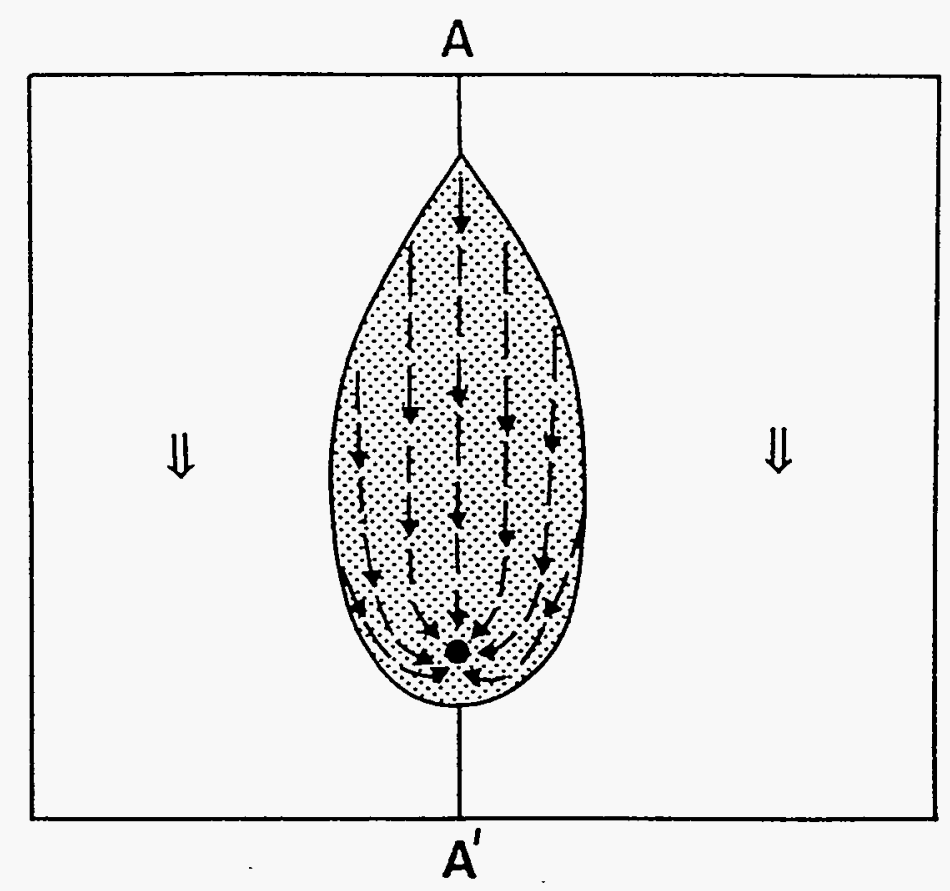

a) Plan view of flow to extraction welk

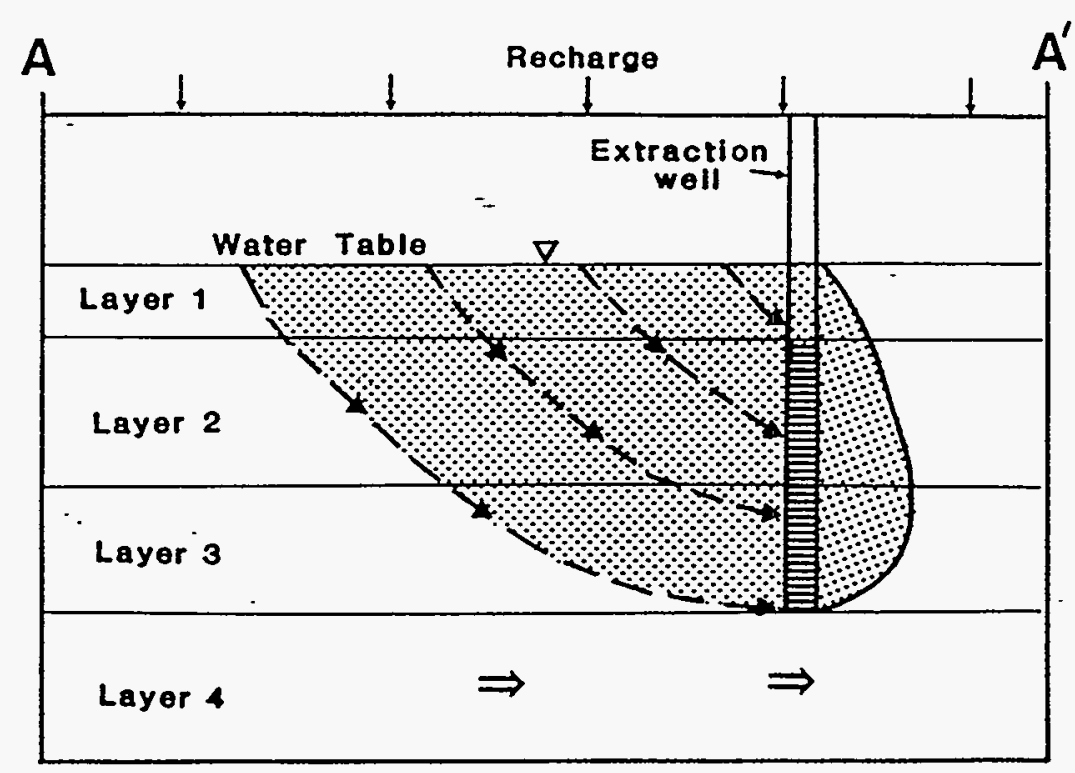

b) Cross-sectional view of flow to extraction well

\section{EXPLANATION}

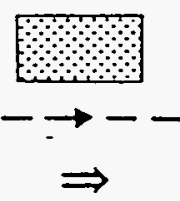

Zone of capture

Projection of typical ground-water flow path with flow direction Direction of reglonal ground-water flow

\section{$\Sigma^{2} \Pi$}

5. S. PAPADOPULOS a ASSOCIATES. INC. CONSULTING GROUND.WATER HYOMOLOGISTE
GENERAL PATTERN OF GROUND WATER FLOW TO AN EXTRACTION WELL IN THE M.AREA
FIGURE 


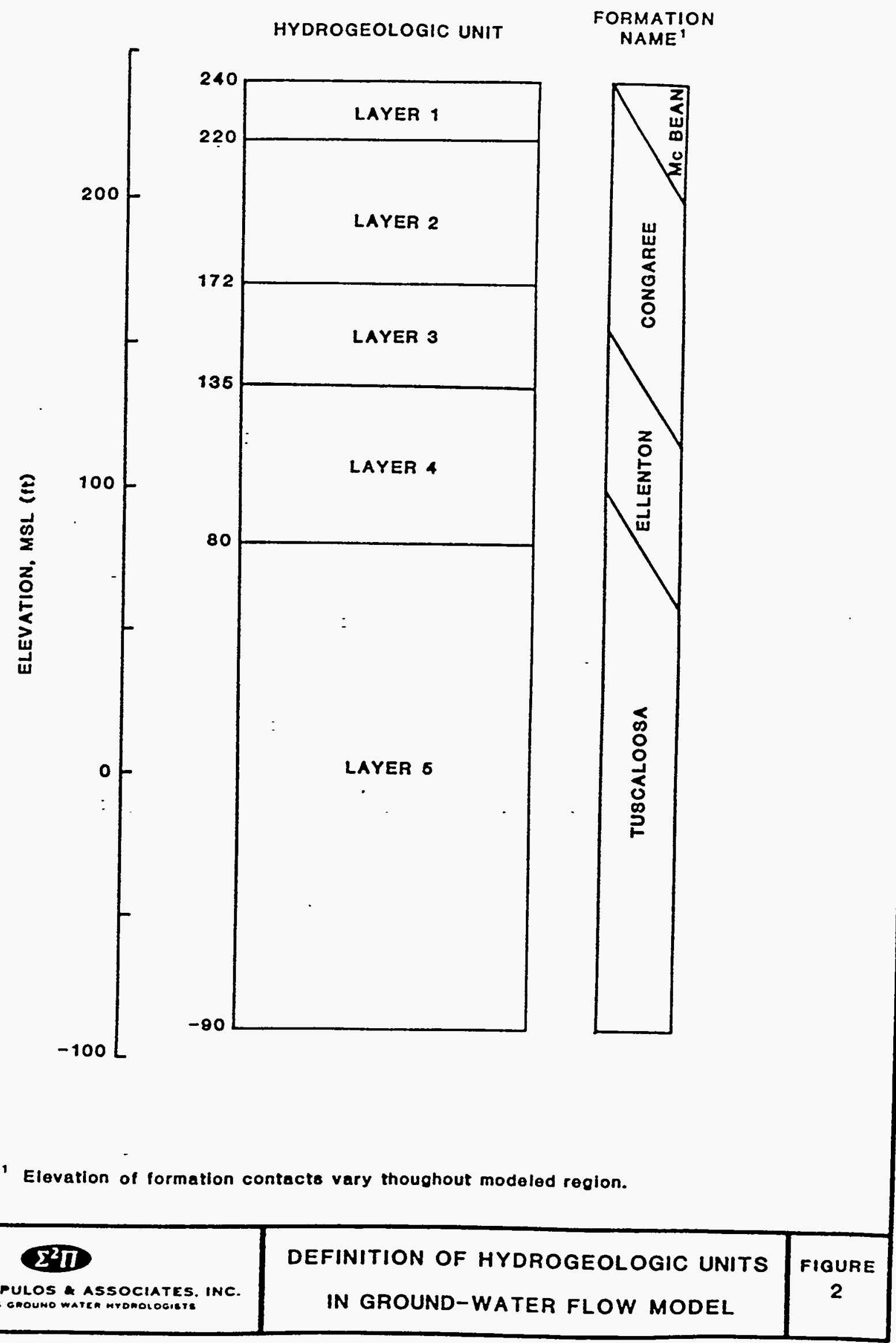




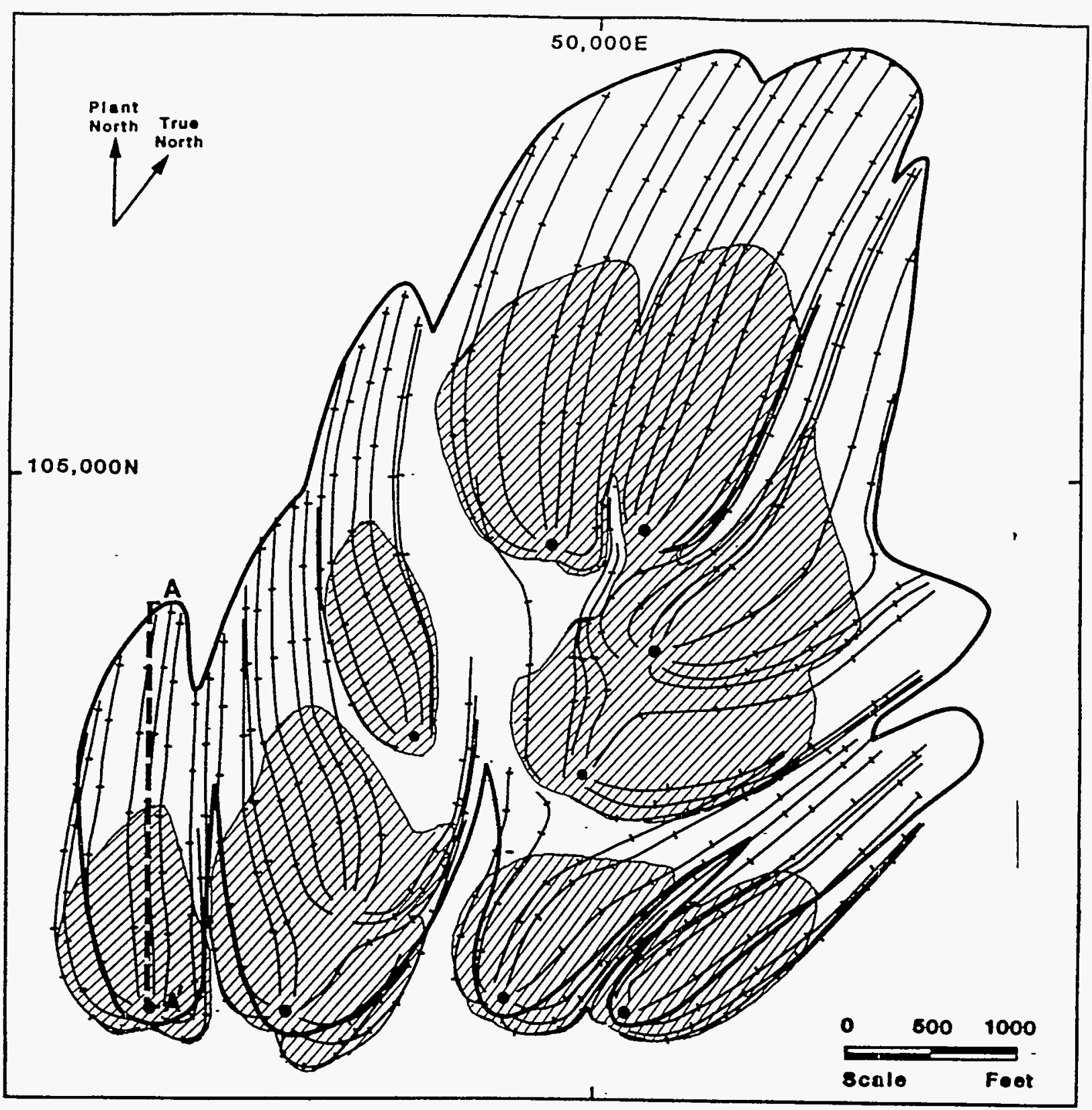

EXPLANATION

Extent of calculated zones of capture at the water-table
Calculated zone of capture in layer 3
Areal projection of typical ground-water flow path.
Travel time between tick marks is five years
Extraction wells




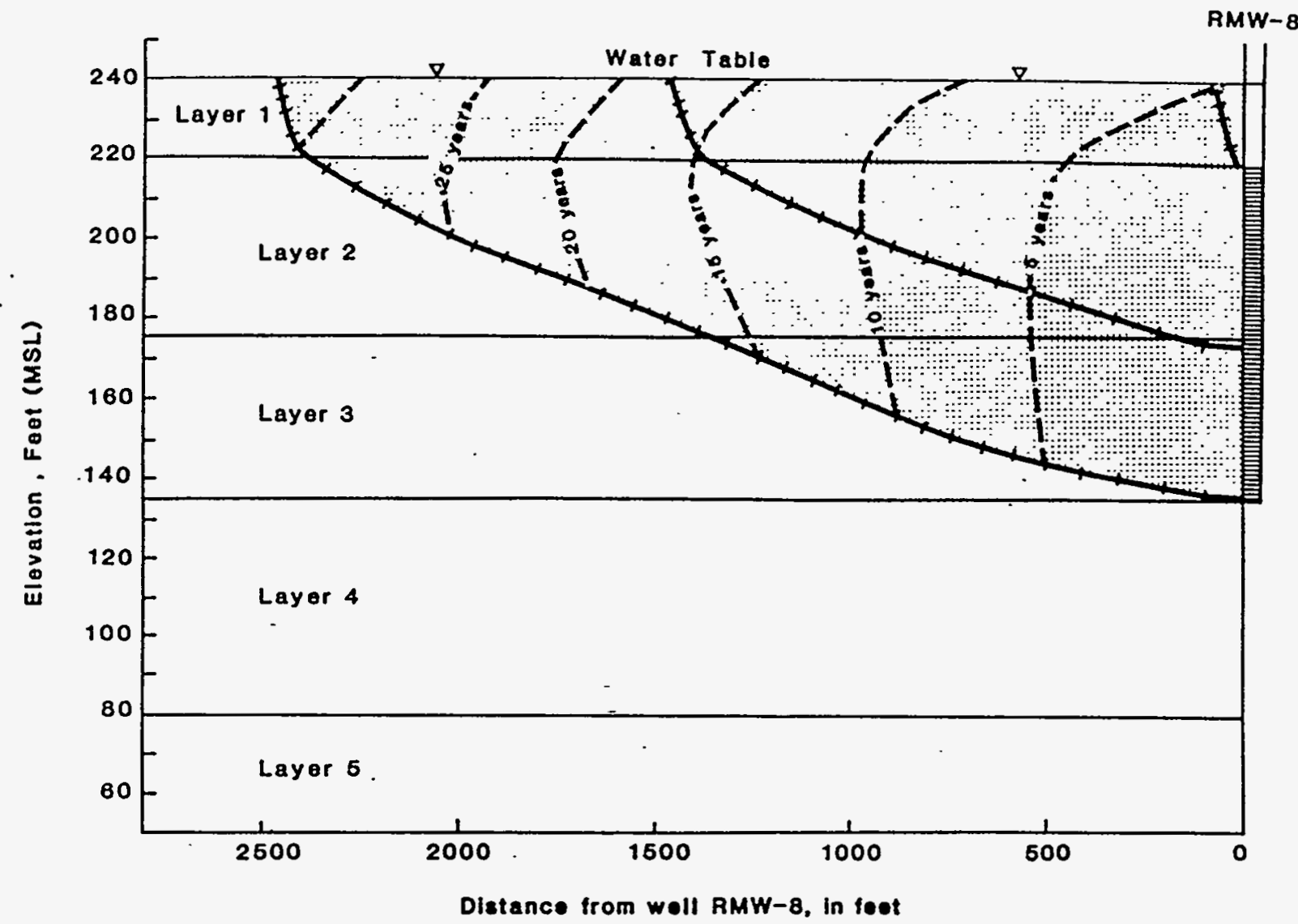

Vertical Exaggeration $=10: 1$

EXPLANATION

Calculated zone of capture.

$\longrightarrow$ Approximate ground-water flow path with flow diraction.

Travel time between tick marks is one year.

- Approximate contour of equal travel times, in years. 


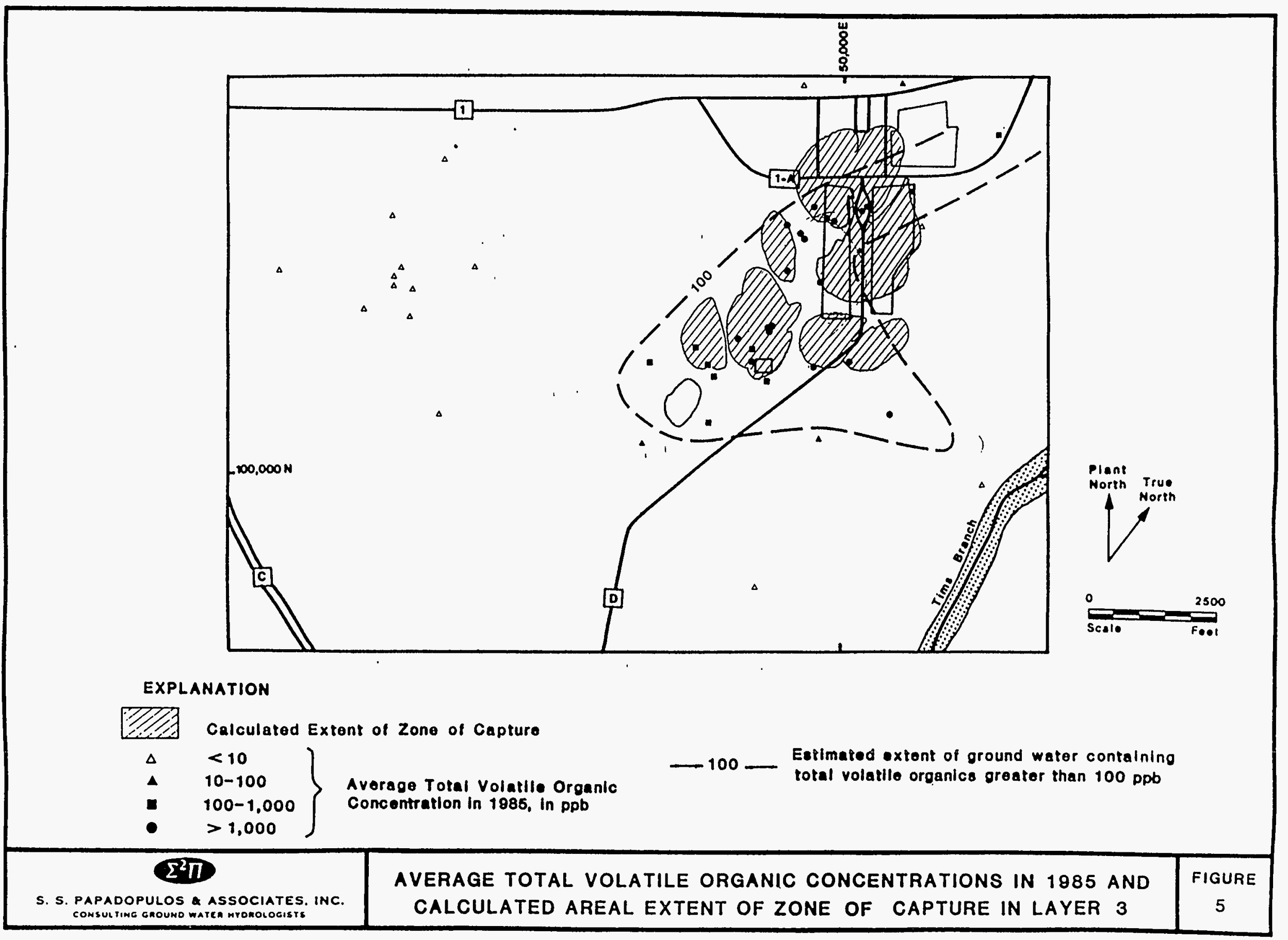




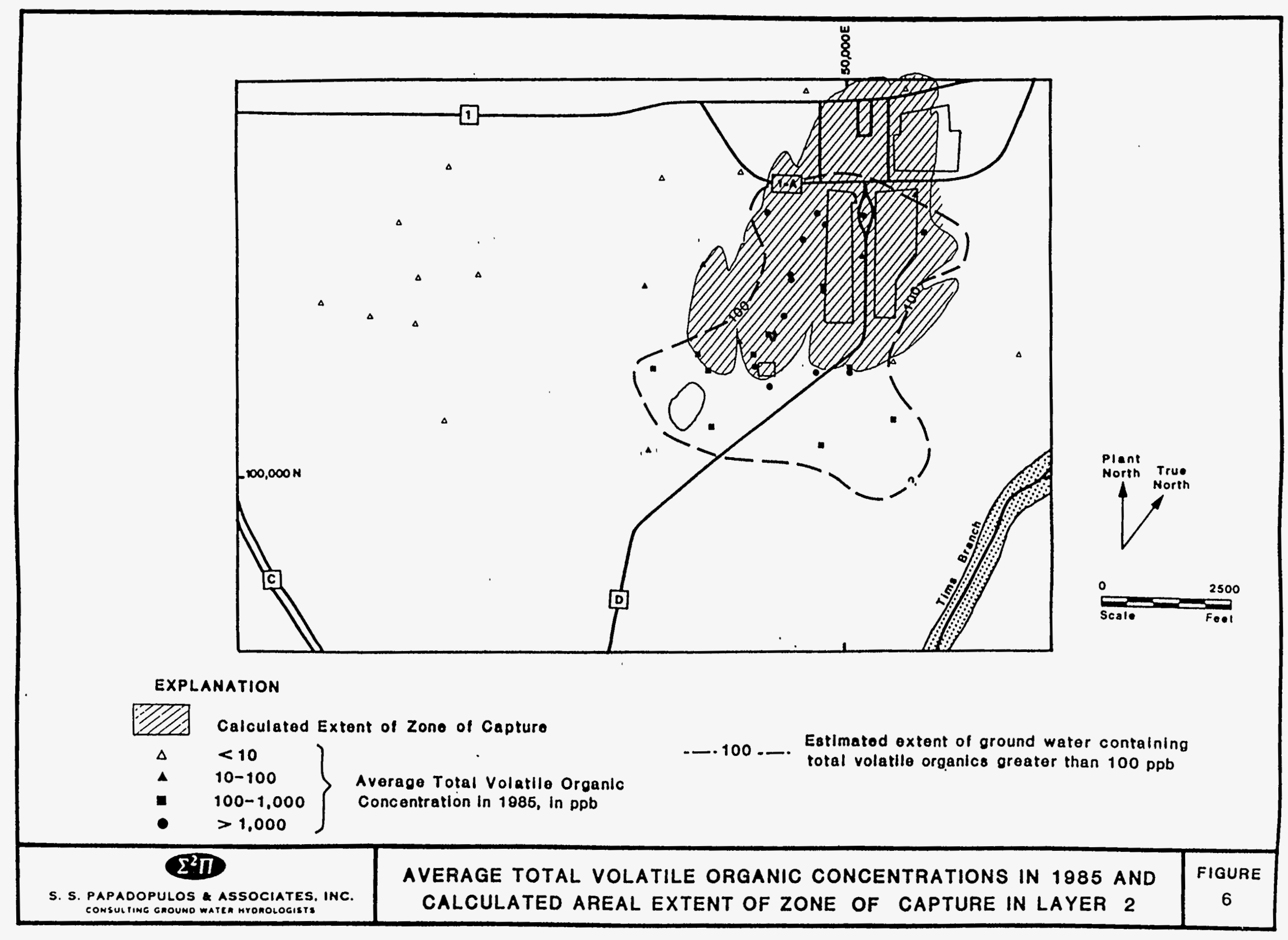




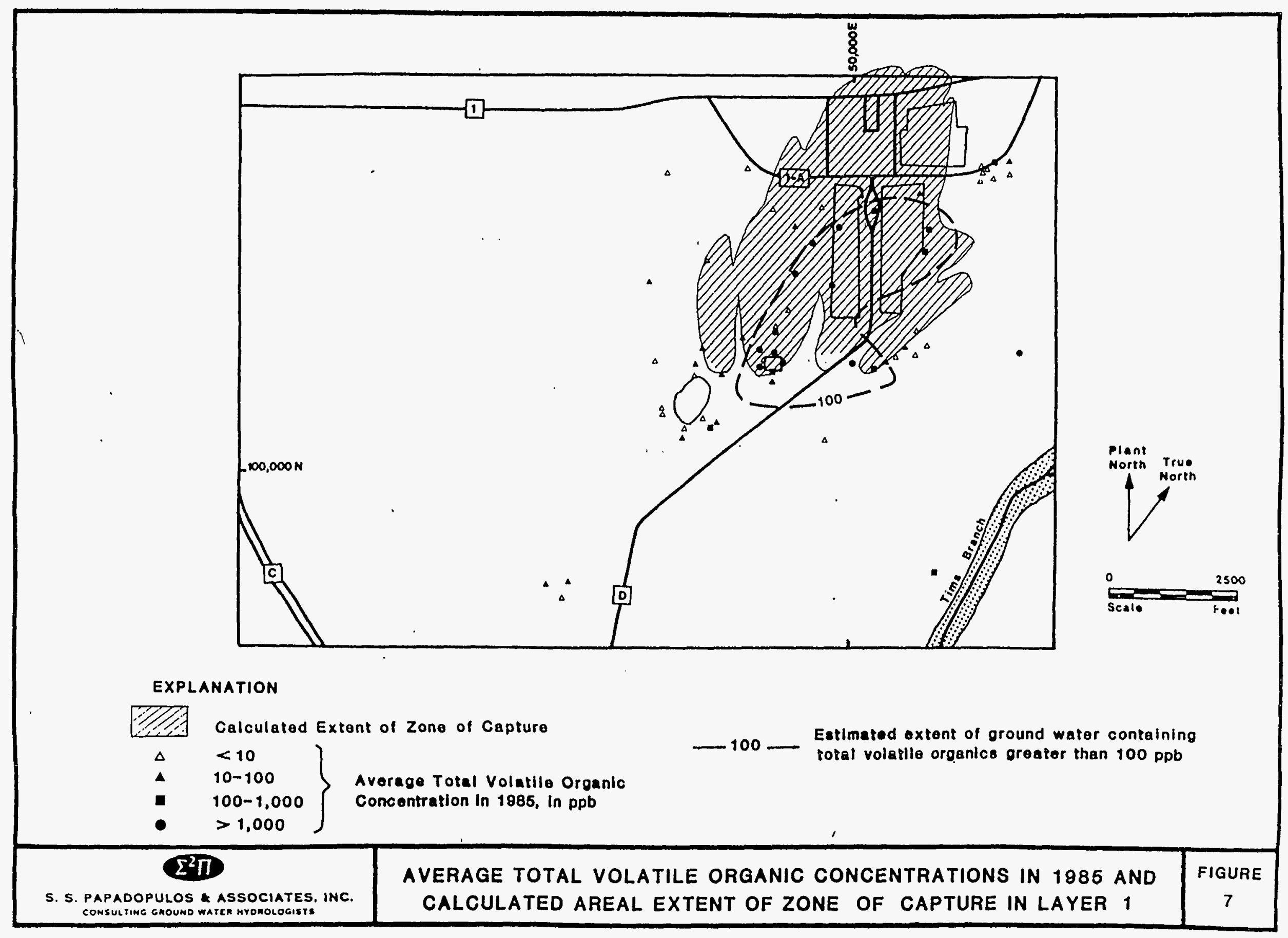


TABLE 1

HYDROGEOLOGIC PROPERTIES USED IN GROUND-WATER FLOW MODEL

Layer

- - -

1

2

3

4

5
Transmissivity

( $\left.\mathrm{ft}^{2} / \mathrm{day}\right)$

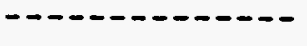

175

2,210

1,290

1,580

12,440
Effective Vertical

Hydraulic Conductivity (ft/day)

.0061

.020

.015

.011

.0065 
TABLE 2

PUMPING RATES OF M-AREA EXTRACTION HELLS

Hell Number

RWM1

RWM2

RHM3

RHM4

RWM5

RHM6

- RWM7

RWM8

RWM9

RWM10

RWM11

Total

\section{Pumping Rate* \\ (gpm)}

25.3

2.2

45.7

34.0

50.6

21.8

26.6

27.8

42.1

31.2

41.6

348.9

* Pumping was distributed equaliy between layers 2 and 3 . Rates are for November 1985. 
<013> DATE-COMPIETED

$<014>$ DATE-OF-RECORD-ENTRY

<015> DATE-RECEIVED

<016> CORIES-RECEIVED

$<020\rangle$ DOCUMENT-TYPE

$<022>$ MEDIUM-CODE

<030> CLAASSIFICATION-CODE

<040> IITERARY-INDICATOR

<050> GPO-SUPERINTENDENT-OF-DOCUMENTS

<072> PERSONAL-AUTHOR-AND-AFEILIATION

Jackson, D. [Du Pont de Nemours (E.I.) and Co., Aiken, SC (United States)] / [Papadopulos (S.S.) and Associates, Inc., Rockville, MD (United States)]

<080> SPONSORING-ORGANIZATION-CODE

<110> TITLE-ENGLISH

Evaluation of the effectiveness of the $M$-Area extraction system

$<150\rangle$ PRIMARY-REPORT-NUMBER

<240> CONTRACT-NUMBER-DOE

<241> ABBREV-CONTRACT-NUMBER-DOE

<242> AWARDING-OFEICE-CODE

$<245>$ LEGIBILITY-CODE

<246> DOE-INITIATING-OFFICE-CODE

<247> MICROFICHE-DISTRIBUTION-CODE

$<248>$ VENDOR-ID-CODE

$<249>$ VENDOR-NAME

$<276>$ DUPCHECK-BYPASS-ELAG

<291> PACKED-PRIMARY-REPORT-NUMBER

$<293>$ PREFIX

<295> INDEX-DOCUMENT-NUMBER

<370> PUBLICATION-DATE

<376> REPORT-TYPE-CODE-AND-FREQUENCY

$<390>$ PAGES-BIBLIOGRAPHIC

<400> REPORT-DISTRIBUTION-CODE

$<421>$ IANGUAGE-CODE

<425> AUDIENCE-CODE

<426> IIMITATION-CODE

<510> DISTRIBUTION-CATEGORY

<520> PROJECT-STATUS

$<530\rangle$ ANNOUNCEMENT-CODE

<540> EDB-SUBJECT-CATEGORIES

<550> SOURCE-OF-BIBIIOGRAPHIC-INPUT

<560> COUNTRY-OF-INTELLECTUAI-ORIGIN

$<570>$ COUNTRY-OF-PUBLICATION

<686> DOCUMENT-STATUS-CODE

$<700\rangle$ CORPORATE-CODE

$<748>$ TAPE-VOL-ISSUE

<749> TAPE-INCOMING-SERIAI-NUMBER

<750> PUBLICATION-VOLUME-SERIAL-NUMBER

<801> SUBJECT-DESCRIPTORS

SAVANNAH RIVER PLANT: T;EXTRACTION APPARATUSES:T;REMEDIAI ACTION: T; PERFORMANCE ;EXPERIMENTAI DATA;VOIATILE MATTER;ORGANIC COMPOUNDS;GROUND
970721

$\mathrm{R}$

Uncl

$\mathrm{N}$

$Y$ SRT-EST--97-186 AC09-89SR18035

SR 18035

09

0

SR

228160-0001-X

WESTINGHOUSE SAVANNAH RIVER CO N

SRTEST97186

$\mathrm{DE}$

M97060148

JuI 1986

T/07/86

21

A

EN

01

UNL,

M -703

$\mathrm{P}$

EDB;ETD;NTS

054000

IMS

US

US

000

$9525316 ; 2202900 ; 9521911$

97R14

AHC29714\%861

WSRC-94T00606; SRS-9712 WATER;ENVIRONMENTAI TRANSPORT;MATHEMATICAI MODELS AILABILITY-CODE
OS;NT




\section{<950> ABSTRACT}

The effect of the $M$-Area extraction system on groundwater flow patterns in the vicinity of the $M$-Area was investigated using the groundwater flow model of the $A-$ and $M$-Areas developed by $S$. $S$. Papadopulos and Associates, Inc. The purpose of this investigation was to: (1) evaluate the performance of the extraction system, in terms of its capability to prevent migration of volatile organic chemicals from the $M$-Area, and (2) evaluate the length of time required to remove groundwater from the capture zones of the extraction wells. The effectiveness of the groundwater extraction system was evaluated by calculating where the groundwater that is pumped from the extraction system enters the groundwater table as recharge, and by calculating the flow paths and travel times for this groundwater from the recharge area to the extraction wells. If the groundwater flow paths to the extraction wells encompass the zones containing the chemicals of concern, the extraction system, if operated long enough, will prevent migration of the chemicals from the $\mathrm{M}$-Area. The time required to reduce the concentrations of the chemicals of concern, the nature of the source of the chemicals, and the interaction of the chemicals with the groundwater environment. This investigation focused on the patterns of groundwater velocity created by the extraction systems, the zones of capture for the extraction wells, and the rate of groundwater evacuation from the capture zones. 